\title{
EFFECT OF THE DRY SEASON ON GROWTH, PRODUCTION OF SEAWEED KAPPAPHYCUS ALVAREZII IN TESABELA WATERS, KUPANG REGENCY, EAST NUSA TENGGARA, INDONESIA
}

\section{MARCELIEN. D J RATOE OEDJOE, YULIANUS LINGGI \& RIDWAN TOBUKU}

Aquaculture Department, Marine and Fisheries Faculty, Nusa Cendana University

\begin{abstract}
Kapaphycus alvarezii is red seaweed (Rhodophyceae) which is a superior commodity of aquaculture in Indonesia. The development of seaweed cultivation areas can be influenced by the biophysical environmental conditions of the waters and climatic conditions. One limiting factor in the cultivation of Kappaphycus alvarezii is the time of cultivation. The purpose of this study is the influence of the dry season on the growth and production of Kappaphycus alvarezii seaweed. Primary data collected in this study include data on seaweed cultivation patterns and cultivation time, namely growth and production data of Kappaphycus alvarezii. Secondary data were obtained from various related agencies including the Climatology Meteorological Agency and the Office of Maritime Affairs and Fisheries. The collected data is analyzed and discussed descriptively accompanied by pictures. The results of this study indicate that the productivity of seaweed development land is strongly influenced by climatic conditions. The existence of climate change both nationally and globally (El Niño and La Niña) greatly affects the time pattern of marine culture in Tesabela. Kapapphycus alvarezii cultivation time generally occurs in months where rainfall is low, namely air temperature (270C - 300 C), salinity 29-31 ppm, pH 7-7.5.The average relative growth rate for $290 \mathrm{C}: 55.7 \mathrm{gr} / w e e k \%$. Temperature of 310C: at 50.9 gr / week\%, temperature at $320 \mathrm{C}-330 \mathrm{C}$ at $40.6 \mathrm{gr} /$ week\%, while at temperature $340 \mathrm{c}-350 \mathrm{c}$ at $29.7 \mathrm{gr} /$ week\%. while production at 29 OC was $72.4 \mathrm{~kg} \mathrm{gr} / \mathrm{m} 2 / \mathrm{six}$ weeks, temperature $310 \mathrm{C}$ is $70 \mathrm{~kg} / \mathrm{m} 2 / 6 w e e k$, temperature 320C, temperature $330 \mathrm{C}$ is $67.8 \mathrm{~kg} / \mathrm{m} 2$ / six weeks, while temperature is $34-350 \mathrm{C}$ is $31.7 \mathrm{~kg} / \mathrm{m} 2$ / six weeks.

KEYWORDS: Kappaphycus Alvarezii, Growth, Production, Season, Water Quality
\end{abstract}

Received: Jun 09, 2020; Accepted: Jun 29, 2020; Published: Jun 30, 2020; Paper Id.: IJMPERDJUN2020300

\section{INTRODUCTION: BACKGROUND}

The dry season can affect the depletion of the volume of water resulting in water turbidity. Changes in this season will affect the life of marine biota, such as its effect on seaweed Kappaphycus alvarezii. This type of Kappaphycus alvarezii seaweed has important economic value because it is a producer of carrageen an. In industry and trade, carrageen a can be used as a raw material for the pharmaceutical, cosmetic, food and other industries (Oedjoe, 2009).

Oceanographic ocean conditions are strongly influenced by monsoons and cross currents. These conditions resulted in three seasons, namely the west season (December-February), the east season (June-August) and the transition season. Yulianto (2004) states that losses on seaweed cultivation are caused by the appearance of the change of seasons from the west to the east season or vice versa. The success of seaweed cultivation depends not only on the method and suitability of the location of the waters, among others, also determined by the season. 
The influence of the season will result in suboptimal growth, production and quality of seaweed. In the dry season the nutrient concentration will be higher than the rainy season so the plankton density is also low (Krismono \& Yayuk 2007: 108). This condition is caused by the dry season with high temperatures which has light penetration and high salinity and evaporation. The effect of the dry season affects the quality of the waters. Water quality is a supporting factor for seaweed growth. For this reason, research on the effect of the dry season on the growth and sea weed production of Kappaphycus alvarezii

\section{METHOD}

The research location of Kappaphycus alvarizii was conducted in Tesabela waters in position $102^{0} 52$,28 “ $-10^{\circ} 18,9^{\prime}$ BT and $00{ }^{0} 16 " 54,1^{\prime}-0{ }^{0} 716,96$ LS(Figure 1)

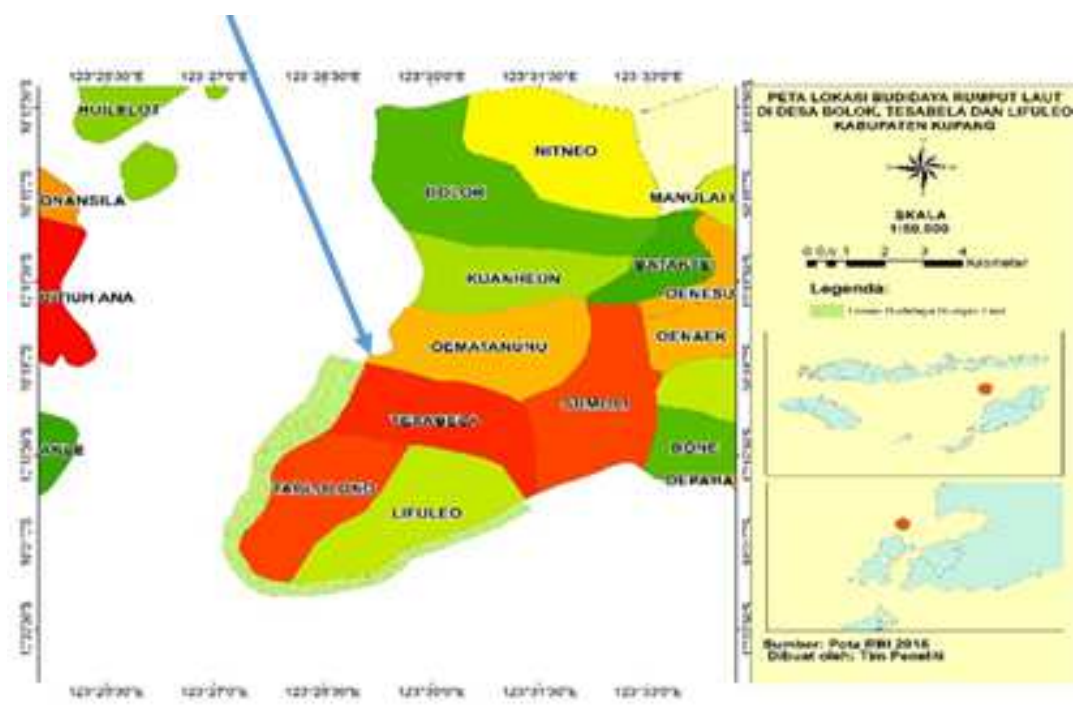

Figure 1: Tesabela Village Research Location.

This research was conducted from May to August 2019. The technology used for aquaculture is the long line method. The initial seed weight of K.alvarezii weighs $100 \mathrm{~g} /$ clump tied to a $100 \mathrm{~cm}$ long ris cord with a distance of $20 \mathrm{~cm}$ between grass points. Each treatment was repeated three times. Data was collected by weighing the wet weight of seaweed once every 7 days for 45 days. Growth parameters include daily growth rate (weight), productivity and carrying capacity of waters for seaweed cultivation, in the form of water quality. Specific Growth Rateis calculated using the formula SGR $=\underline{\ln }$ $\underline{\mathrm{Wt}}$ - In Wo x 100\% (Andersen, 2005),

While Productivity is calculated using the formula: Seaweed Production $(\mathrm{P})=\mathrm{Wt}-\mathrm{W} 0$ / A (Sediadi and Budiajo, 2000).

Where:

$$
\begin{aligned}
& \mathrm{A}=\text { Area of maintenance }\left(\mathrm{m}^{2}\right) \\
& \mathrm{P}=\text { Seaweed production }\left(\mathrm{kg} / \mathrm{m}^{2}\right) \\
& \mathrm{W}_{\mathrm{t}}=\text { Final weight of seaweed }(\mathrm{kg}) \\
& \mathrm{W}_{0}=\text { initial weight of seaweed }(\mathrm{kg}) \\
& \mathrm{t}=\text { cultivation time }
\end{aligned}
$$




\section{RESULTS AND DISCUSSIONS}

\section{Water Quality}

Water quality is a supporting factor for seaweed growth. Water quality data at the study site (Table 1) are as follows: the average temperature at the same location is $30^{\circ} \mathrm{C}-34^{0} \mathrm{C}$. Dissolved oxygen (Dissolved Oxygen) of $5.40-6.70 \mathrm{ppm}$ generally shows a normative value like table 1 .

Table 1: Water Quality at Tesabela

\begin{tabular}{|c|l|c|c|}
\hline No & \multicolumn{1}{|c|}{ Parameter } & Research Sites & $\begin{array}{c}\text { Quality Standards } \\
\text { Kep.Men LH, 2004) }\end{array}$ \\
\hline 1 & Temperature $\left({ }^{0} \mathrm{C}\right)$ & $29-34$ & $29-31$ \\
\hline 2 & Salinity $(\mathrm{ppm})$ & $30-36$ & $30-33$ \\
\hline 3 & DO $(\mathrm{ppm})$ & $5,40-6,70$ & $>5 \mathrm{ppm}$ \\
\hline 4 & $\mathrm{pH}$ & $5,7-8,5$ & $7,00-8,50$. \\
\hline 5 & Brightness (m) & $1,0-5$ & $1-10$ \\
\hline 6 & Current $(\mathrm{Cm} / \mathrm{det})$ & $20-32$ & $20-30$ \\
\hline 7 & Nitrat $(\mathrm{ppm})$ & 0,005 & 0,008 \\
\hline 8 & Fosfat $(\mathrm{ppm})$ & 0,04557 & 0,015 \\
\hline
\end{tabular}

The water temperature in Tesabela during the study was $30{ }^{0} \mathrm{C}-34^{0} \mathrm{C}$. While the optimum temperature for K.alvarezii was around $29^{\circ} \mathrm{C}-30^{\circ} \mathrm{C}$ in April - June 2019 (Figure 2). As explained by (Kep.Ment LH, 2014) that the temperature for the growth of K.alvarezii seaweed $29^{0} \mathrm{C}-31^{0}$ C. According to SNI (7579.2: 2010) that K.alvarezii seaweed can live in a temperature range of $27^{\circ} \mathrm{C}-30^{\circ} \mathrm{C}$. Ambas (2006) further stated that K.alvarezii could still tolerate temperature fluctuations of $40{ }^{\circ} \mathrm{C}$. The $\mathrm{pH}$ range is $5.7-8.5$ or the average $\mathrm{pH}$ is 7.1 . This $\mathrm{pH}$ value is still as described by Kep. Men LH (2004), which is 7.00 - 8.50 (Like in Figure 2 and 3)
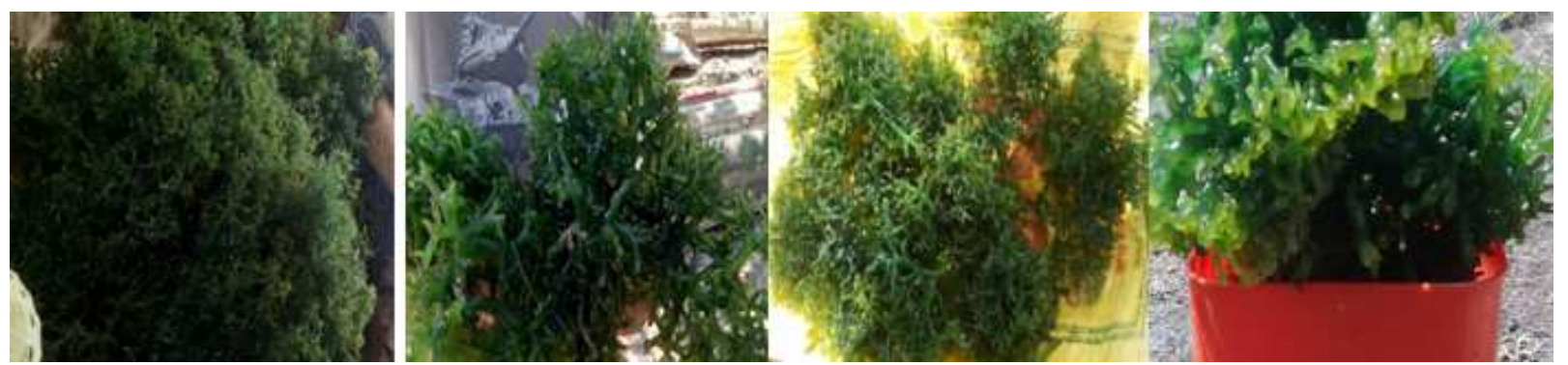

Figure 2: K. Alvarezii Condition at 290C - 300 C in Tesabela Waters, April -June 2019.

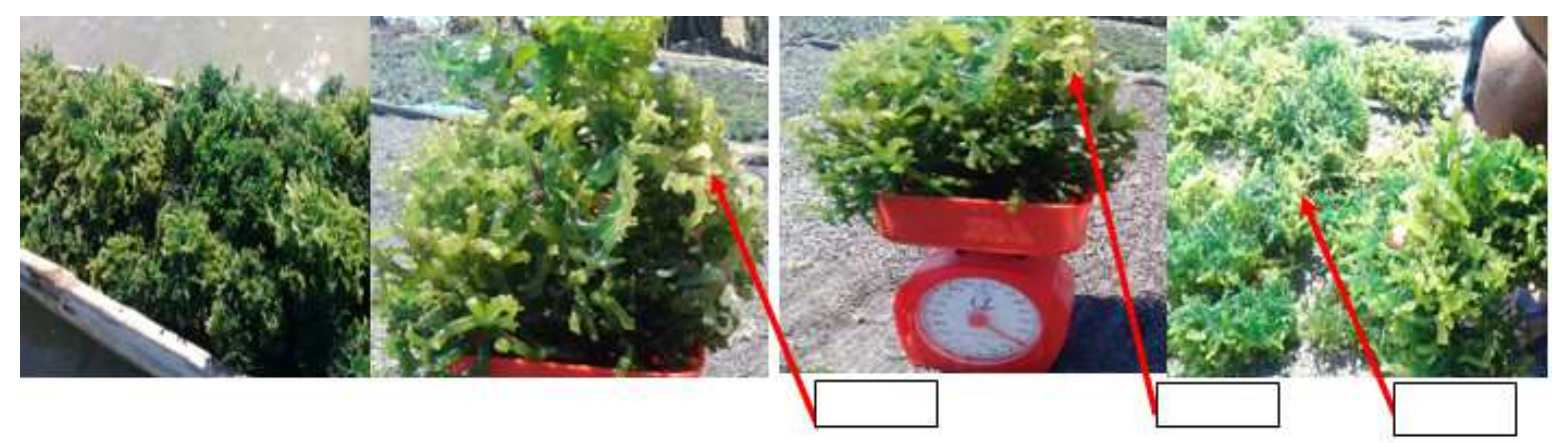

Figure 3: K. Alvareziicondition at 320C - 35 0Cin Tesabela Waters, Juli - Agustus 2019. 


\section{GROWTH AND PRODUCTION OF KAPPAPHYCUS ALVAREZII}

\section{Production of Kappaphycus Alvarezii}

The production of K.alvarezii at the temperature of the waters of $29{ }^{\circ} \mathrm{C}-30^{\circ} \mathrm{C}$ were $72.4 \mathrm{~kg} \mathrm{gr} / \mathrm{m} 2 / 6$ weeks, the temperature of $31^{\circ} \mathrm{C}$ were $70 \mathrm{~kg} / \mathrm{m} 2 / 6$ weeks, the temperature were $32{ }^{\circ} \mathrm{C}$, the temperature of $33{ }^{\circ} \mathrm{C}$ was $67.8 \mathrm{~kg} / \mathrm{m} 2$ / 6weeks, while the temperature is $34^{0} \mathrm{C}-35^{\circ} \mathrm{C}$ were $31.7 \mathrm{~kg} / \mathrm{m} 2 / 6$ weeks.

\section{Specific Growth Rate of Kappaphycus Alvarezii}

The results of the analysis show that there are significant differences $(\mathrm{p} \leq 0,05)$ for places and seasons at specific growth rates. The average specific growth rate for $29{ }^{\circ} \mathrm{C}-30{ }^{\circ} \mathrm{C}$ waters was $55.7 \mathrm{~g} /$ week\%. temperature of $31{ }^{\circ} \mathrm{C}$ at 50.9 gr / week\%, temperature at $32{ }^{\circ} \mathrm{C}$, temperature at $33{ }^{\circ} \mathrm{C}$ at $40.6 \mathrm{gr} /$ week $\%$, while at temperature $34-35{ }^{\circ} \mathrm{C}$ at $29.7 \mathrm{gr} /$ week\%. The low growth is due to the influx of the dry season from June to August 2019 with temperatures around $33{ }^{\circ} \mathrm{C}-35^{\circ} \mathrm{C}$.

\section{CONCLUSIONS}

Season and water quality of affect the growth and production of $K$. alvarezii. The highest growth and production at temperatures of $29{ }^{\circ} \mathrm{C}-30{ }^{\circ} \mathrm{Con}$ April - June. In April - June there were no ice-ice disease

\section{ACKNOWLEDGMENTS}

This research was carried out at the expense of Marine and Fisheries Faculty, Nusa Cendana University, Fiscal Year 2019 with No: 13 / SK / FKP / 2019, February 22, 2019

\section{REFERENCES}

1. Amiluddin, N M. 2007, Study of Growth and Content of Carrageenan Kappaphycus alvarezii affected by ice-ice in the waters of Pulau Pari, Thousand Islands. (Thesis). Bogor. Postgraduate Program, Bogor Agricultural University.

2. Ambas, I. 2006. Sea Cultivation Training (Coremap Phase 2 Selayar Regency).

3. Seaweed Cultivation. Makassar. Mattirotation Foundation.

4. Arfah, A and S. Papalia. 2008. Growth rate of Eucheuma cottonii (Rhodophyta)

5. at Different Planting Periods in Osi Seram Island WatersWest. Journal of Fisheries and Marine Torani

6. Farid, A. 2008. Environmental Study for Eucheuma Cottonii Seaweed Cultivation inBranta waters, Pamekasan, Madura. Journal of Fisheries Research Volume 2, No: $1: 1-6$.

7. Kurnianto, D and Teddy Triandiza. 2013.Effect of season on Growth and Results of Eucheuma cottonii Grass Planted in two water Locations in Soutj Maluku. National Seminar on Science \& Technology V Research Institute of Lampung University, 1920 November 2013

8. Oedjoe Ratoe M,Dj., 2009., Effect of Temperature on Seaweed Ice-Ice Disease (Eucheuma cottonii) Faculty of Mathematics and Natural Sciences Undana / Bios Journal, 5 (1): 22-27.

9. Sorokin, C. 1973. Dry Weight, Packed Cell and Optical Density. Dalam: Janet Stein (eds). Phycologycal Methods Culture Method and Growth Rate Measurement.

10. Cambridge University Press. Cambridge, U. K, p: 322. Wikipedia. 2011. Faktor Produksi. http://id.wikipedia. org/wiki/Faktor_produksi. (Diakses tanggal 8 Agustus 2019) 
11. Yulianto, K. 2003. Observation of the disease "ice-ice" and algae competitor phenomena causes of harvest failure of seaweed cultivation (Kappaphycus alvarezii (C)Agardh) on Pari Island, Thousand Islands in 2000 and 2001. Seminar PaperNational National Maritime Research and Technology. Jakarta, July 30-31, 2003.

12. Yulianto, K. 2004. The Phenomenon of the Controlling Factors Causing Loss to Cultivation Karaginophit in Indonesia. Oseana, Volume Xxix, Number 2, 2004: 17-23

13. Astalakshmi, A., et al. "Evaluating the potentiality of leaves of Manilkarazapota (L.) P. Royan and Mimusopselengi L. in the synthesis of silver nanoparticles." International Journal of Metallurgical \& Materials Science and Engineering (IJMMSE) 4.2 (2014): 25-36.

14. O C, Akakuru, and Akudinobi B E B. "Determination of Water Quality Index and Irrigation Suitability of Groundwater Sources in Parts of Coastal Aquifers of Eastern Niger Delta, Nigeria." International Journal of Applied and Natural Sciences (IJANS) 7.1 (2018): 1-6.

15. Suman, Ashok Kumar, et al. "Assessmentof Water Quality and Fish Growth in Micro-Water Sheds of Banswara District in Southern Rajasthan." IMPACT: International Journal of Research in Applied, Natural and Social Sciences (IMPACT: IJRANSS) 5.1 (2017):111-120

16. Khwakaram, Ahmed I. "Effects of Fat, Oil and Grease (FOG) Discharge Pollutants on Water Quality of Qalyasan Stream, Tanjero River and Impact of Fat, Oil and Grease on Darbandikhan Reservoir in Sulaimani City-Kurdistan Region of IraqIraq." International Journal of Environment, Ecology, Family and Urban Studies (IJEEFUS) 6.1 (2016): 1-12.

17. Yusuf, Yakubu Obadaki, and Joseph David Ariko. "Effect of Dumpsites on Ground Water Quality in Zaria Metropolis, Kaduna State, Nigeria." BEST: International Journal of Humanities, Arts, Medicine and Sciences (BEST: IJHAMS) 2.5 (2014):1-10 

